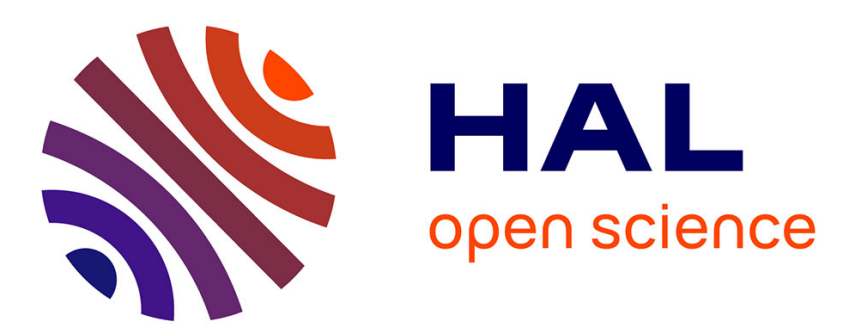

\title{
New insights into the termination of the African Humid Period (5.5 ka BP) in central Ethiopia from detailed analysis of a diatom record
}

\author{
V. Roubeix, F. Chalié
}

\section{- To cite this version:}

V. Roubeix, F. Chalié. New insights into the termination of the African Humid Period (5.5 ka BP) in central Ethiopia from detailed analysis of a diatom record. Journal of Paleolimnology, 2019, 61 (1), pp.99-110. 10.1007/s10933-018-0047-7 . hal-01945413

HAL Id: hal-01945413

https://hal.science/hal-01945413

Submitted on 5 Dec 2018

HAL is a multi-disciplinary open access archive for the deposit and dissemination of scientific research documents, whether they are published or not. The documents may come from teaching and research institutions in France or abroad, or from public or private research centers.
L'archive ouverte pluridisciplinaire HAL, est destinée au dépôt et à la diffusion de documents scientifiques de niveau recherche, publiés ou non, émanant des établissements d'enseignement et de recherche français ou étrangers, des laboratoires publics ou privés. 
1 New insights into the termination of the African Humid Period (5.5 ka BP) in central Ethiopia

2 from detailed analysis of a diatom record

3

4 Vincent Roubeix ${ }^{1}$ and Françoise Chalié ${ }^{2}$

5

$6{ }^{1}$ Irstea, UR RECOVER, Pôle AFB-Irstea hydroécologie plans d'eau, Centre d'Aix en Provence,

73275 route Cézanne, 13182 Aix-en-Provence (France)

8 email : vincent.roubeix@irstea.fr

9

$10 \quad$ 2 Aix-Marseille Université, CNRS, IRD, Coll.France, CEREGE, BP 80, F.13545 Aix-en-Provence

11 (France)

12 email : chalie@cerege.fr

13

14 Keywords : African monsoon; Climate change; Early warning signals; Regime shift; Ecological

15 thresholds

16

17

18

19 This is a post-peer-review, pre-copyedit version of an article published in Journal of Paleolimnology. The final

20 authenticated version is available online at: http://dx.doi.org/10.1007/s10933-018-0047-7 
2 ABSTRACT

3 The termination of the African Humid Period in northern Africa has been described as abrupt,

4 occurring within centuries, as well as gradual, in response to incremental decreases in summer

5 insolation. This study examined the rapidity of the change in diatom assemblages over the period

6 from 6.5 to $4.5 \mathrm{cal}$ ka BP, in a core studied previously at a coarser resolution. This transition was

7 characterized by high variability of assemblages, which could be related, in part, to changes in

8 water conductivity, and potentially enhanced by a site-specific hydrological threshold or ecological

9 salinity threshold. We hypothesize that the variations in diatom assemblages reflect climate

10 fluctuations, which may have been an early warning signal of an impending climate regime shift. 


\section{Introduction}

3 The end of the African Humid Period is one example that shows the Holocene was not characterized

4 by a stable climate (deMenocal and Bond 1997; Gasse 2001). It took place at ca. 5.5 ka BP in north

5 subtropical Africa and gave rise to the Sahara Desert, where there had previously been savanna and

6 lakes for several millennia. Analysis of a marine sediment core near the northwest coast of Africa

7 suggested that this mid-Holocene climate change was abrupt and occurred within centuries

8 (deMenocal et al. 2000). The abruptness of the transition, however, is contradicted by other archives

9 that show more gradual, millennial-scale aridification of the climate (Kröpelin et al. 2008). It seems

10 that rapid termination of the African Humid Period (within 500 years) concerned exclusively the

11 regions of the western Sahara and Eastern Africa (Tierney and deMenocal 2013).

12 The onset and termination of the African Humid Period is often cited as an example of a

13 regime shift (Scheffer and Carpenter 2003; Walker and Meyers 2004; Seddon et al. 2014). The

14 external trigger was summer solar radiation, which varied continuously following Earth's axis angle

15 and reached a maximum at ca. 9000 years BP. Non-linear responses of precipitation and vegetation

16 were reconstructed as a threshold of insolation was crossed (deMenocal et al. 2000). This radiation

17 threshold was associated with climatic and ecological (through vegetation) positive feedbacks,

18 which accelerated climate change (Tierney and deMenocal 2013).

19 Paleoclimate indicators can provide information about the timing of the transition from

20 humid to arid conditions in the North African subtropical band. An indicator can show early

21 warning signals that a regime shift is going to occur, in particular through an increase of variance

22 (Wang et al. 2012). Interpretation of a climate proxy, however, may be complicated if it is not

23 linearly related to climate, and if its variations are influenced by site-specific thresholds (Kröpelin

24 et al. 2008). 
Analysis of diatoms in a core from Lake Abiyata, Ethiopia, revealed important changes in

2 climate during the Holocene (Gasse 2001; Chalié and Gasse 2002). A striking result was an abrupt

3 increase in diatom-inferred conductivity (lower precipitation-evaporation balance) and a decline in

4 the proportion of planktonic diatoms (shallower lake) around $5.5 \mathrm{ka} \mathrm{BP}$. This suggests rapid (one to

5 a few centuries) aridification of the climate, synchronous with the documented termination of the

6 African Humid Period. Interestingly, a short peak of diatom-inferred conductivity preceded the

7 large increase that marked the beginning of a period of high conductivity. The sampling frequency

8 and indicators that were used, however, were not sufficient for a detailed investigation of this

9 important climate transition.

Lake Abiyata is today a shallow hyper-alkaline lake located in the Ethiopian rift at an

11 elevation of $1600 \mathrm{~m}$. It is part of the endorheic Ziway-Shalla system, composed of four residual

12 lakes. Lake Abiyata receives surface inflow from Lakes Ziway and Langano and has no surface

13 outlet. Its present area is $176 \mathrm{~km}^{2}$ and it has an average depth of $7.6 \mathrm{~m}$ and a maximum depth of

$1414.2 \mathrm{~m}$ (Ayenew 2007). During the African Humid Period, the four lakes merged to form a single

15 large lake (Gillespie et al. 1983).

16 The objective of this study was to describe the ecological turnover of diatom assemblages in

17 Lake Abiyata at the end of the African Humid Period and to investigate the information diatoms can

18 provide about lake and climate changes. To this end, additional diatom analyses were undertaken on

19 the core from Lake Abiyata, focusing on the period 6.5 to $4.5 \mathrm{ka} \mathrm{BP}$, so that the transitional state

20 between the African Humid Period and the late Holocene could be quantified climatically. 


\section{Materials and methods}

3 Coring and sampling

4

5 Sediment core AB95II was collected in 1995 using a Wright corer, in the eastern part of Lake

6 Abiyata $\left(7^{\circ} 35^{\prime} \mathrm{N}\right.$; $\left.38^{\circ} 35^{\prime} \mathrm{E}\right)$, at a water depth of $7 \mathrm{~m}$. With respect to the section considered here

7 (560-862 cm depth in the core), the sediments were described soon after core opening and splitting,

8 and consisted mainly of a brown, to grey and greenish, organic-rich mud, with a few cm-thick

9 layers of fine sand and cinerite interrupting the mud. Eleven new samples were taken in the core

10 section, adding to the 18 samples analyzed in a previous study (Chalié and Gasse 2002). Each of the

1129 samples integrated $1 \mathrm{~cm}$ of sediment thickness. Samples were collected at intervals of 2.2 to 24

$12 \mathrm{~cm}$, owing to the lithology, in particular the presence of sand or cinerite layers, and to the

13 availability of well-preserved sediment that remained in the core.

15 Chronology

17 We used the sediment chronology developed in a previous study of the core (Chalié and Gasse

18 2002). The chronological framework was based on radiocarbon dates on bulk organic matter (OM)

19 (Gibert et al. 1999). Ages were considered valid because (1) the OM was shown to be mainly of

20 phytoplankton origin and (2) the ${ }^{14} \mathrm{C}$ activity of the total dissolved inorganic carbon from the

21 modern lake water is in equilibrium with that of atmospheric $\mathrm{CO}_{2}$. Dates obtained on carbonated

22 material formed at the water-sediment interface showed ages that were too old by 500 to 900 years,

23 probably as a consequence of groundwater inputs that contained dead carbon. These dates were

24 therefore excluded from our chronological framework. The radiocarbon timescale was established 
1 by linear interpolation between adjacent dated levels. The calendar timescale was calibrated with

2 CALIB \#4.0 (Stuiver and Reimer 1993; Stuiver et al. 1998; URL address: http://calib.org/calib/).

3 Three dates were obtained within the depth interval of interest (571.9 to $861.5 \mathrm{~cm}$ depth).

4 Two other dates were obtained from sediment samples collected in the core $<25 \mathrm{~cm}$ below and

5 above the section considered. These 5 dates were in order between 3900 +/- 90 (551.8 cm depth),

6 and $7100+/-80(885.1 \mathrm{~cm}$ depth $){ }^{14} \mathrm{C}$ years BP. Based on these 5 dates, the mean sedimentation rate

7 was $\sim 0.70 \mathrm{~mm} \mathrm{a}^{-1}$, and doubled at ca. $6070 \mathrm{cal} \mathrm{a} \mathrm{BP}$ to $\sim 1.40 \mathrm{~mm} \mathrm{a}^{-1}$, and the chronological

8 framework was considered well constrained during the period of interest. Unless specified

9 otherwise, ages presented in this study are in calendar ka BP.

11 Sample preparation and diatom enumeration

13 Organic matter was oxidised with $\mathrm{H}_{2} \mathrm{O}_{2}$ and carbonates were removed with $\mathrm{HCl}$. Slides were 14 mounted in a high-refractive-index resin (Naphrax@) and observed using light microscopy 15 (magnification x1000). Diatom taxonomy was based on African (Hustedt 1949; Gasse 1986;

16 Cocquyt 1998) and European floras (Krammer and Lange-Bertalot 1986, 1988, 1991a,b).

18 Conductivity transfer function

20 The conductivity transfer function used was based on the Weighted Averaging Method (WAM; ter

21 Braak and Loomans 1986; Gasse et al. 1995). The modern reference database used was the African

22 component of the database from the EDDI Program (European Diatom Database Initiative)

23 (Battarbee et al. 2000), hereafter referred to as the modern African dataset. Details of the methods

24 can be found in Chalié and Gasse (2002). In the latter study, past pH and ionic ratios were also

25 inferred for Lake Abiyata using other transfer functions, but it was shown that their variations were 
1 highly correlated to conductivity. The present study therefore focused on conductivity, which is also

2 the variable most directly related to the precipitation-evaporation balance and climate change. Two

3 notable sources of uncertainty in the transfer function are: (1) the difference in temporal integration

4 of water samples and diatom sediment samples in the training dataset (especially for lakes having

5 high seasonal variability), and (2) interactions between potential confounding factors (Juggins

6 2013). The transfer function was applied here, however, in its field of calibration and its

7 performance with respect to water conductivity reconstruction (Gasse et al 1995) suggests that such

8 uncertainties are minimal. Most of the species present in the core section of interest were included

9 in the transfer function (90\%).

11 Data analysis

13 All data analyses were performed with R (R Core Team 2016). Correspondence analysis (CA) was

14 applied to species relative abundance data to show variations in diatom assemblages through time.

15 Only species having a maximum relative abundance in the sequence greater than $2 \%$ were

16 considered $(n=28)$. Sample coordinates in each of the three main dimensions of CA (CA1, CA2 and

17 CA3) were plotted against sample age estimated from the core age model. Groups identified in the

18 CA were characterized by indicator species, determined by IndVal analysis using the labdsv R

19 package (David 2016).

20 Individual species relationships to water conductivity were examined using the modern

21 African dataset. Moreover, the responses to the conductivity gradient of all species present in the

22 dataset were evaluated through a single gradient forest analysis. Gradient forest is a machine

23 learning method to extract ecological community thresholds from the crossing of species and

24 environment tables. It is a kind of breakpoint analysis that considers many species and

25 environmental variables together. It is based on the development of a random forest for each species 
1 and the analysis of data splits produced by all specific models on every environmental gradient

2 (Ellis et al. 2012; Roubeix et al. 2016). In addition to threshold detection, gradient forest estimates

3 the relative importance of environmental variables in species distribution among sites. Log-

4 transformed diatom species relative abundances in the sediment samples of the modern African

5 dataset were considered for the analysis. Five hydrochemical variables were used to run the

6 analysis: $\mathrm{pH}$, alkalinity, conductivity, anion $\left(\mathrm{HCO}_{3}{ }^{-}+\mathrm{CO}_{3}{ }^{-}\right) /\left(\mathrm{Cl}^{-}+\mathrm{SO}_{4}{ }^{2-}\right)$ and cation

$7\left(\mathrm{Na}^{+}+\mathrm{K}^{+}\right) /\left(\mathrm{Ca}^{2+}+\mathrm{Mg}^{2+}\right)$ ratios. Their correlations in the dataset were moderate $(<0.5$ Spearman $)$,

8 except between conductivity and alkalinity (0.53), alkalinity and cation ratio (0.56), and

9 conductivity and anion ratio (-0.69). Potential thresholds identified by gradient forest were

10 considered in the conductivity gradient.

\section{Results}

14 The application of the conductivity transfer function to the sediment samples collected in the time

15 interval 6.5 to 4.5 ka BP shows that there was a second sharp increase in conductivity after the short

16 peak at 5.7 ka BP (Fig. 1). This increase at ca $5.3 \mathrm{ka}$ BP was followed by a period of relatively

17 stable and high conductivity until 4.5 ka BP. When reconstructed water conductivity is considered

18 alone, the change in lake chemistry appears rather abrupt if one omits the single peak at $5.7 \mathrm{ka}$ BP.

19 The CA on diatom assemblages, however, reveals a transition period between two relatively stable

20 states (Fig. 2). This transition period lasted approximately 600 years, and was characterized by

21 important variations through time of the diatom assemblages, as shown by the distance between

22 successive samples in the plot formed by the two major dimensions of the CA $(34 \%+24 \%=58 \%$

23 eigenvalue). The indicator species of the group of samples preceding the transition belong mostly to

24 the genera Fragilaria and Stephanodiscus (Table 1). Among the indicator species that characterize

25 the samples following the transition are two with high IndVal values: Anomoeoneis sculpta and 
1 Rhopalodia gibberula. During the transition period, one sample comes very close to the later stable

2 group (Fig. 2).

The turnover of diatom assemblages along CA1 is very similar to the plot of diatom-inferred

4 conductivity (Figs. 1 and 2b). This means that CA1 is related to the abundance of the main indicator

5 species of high conductivity (e.g. Anomoeoneis sculpta). It appears clearly that the two stable

6 groups of samples correspond to two successive states of the lake, with low and then high water

7 conductivity. The sample of the first group that appears close to the second group in the CA plot is

8 at the top of a very narrow peak of conductivity, reaching the level of the latest samples of the

9 studied sequence (Fig. 2b). Along CA2, the diatom assemblage variations during the transition

10 period are not correlated to inferred changes in conductivity. Variability between the two stable

11 states is strongly enhanced, with up and down variations extending beyond the interval between the

12 initial and final states. The pattern is similar along CA3, although the coordinates of the two stable

13 states are almost equal and the variability is a bit lower. Regarding variations in CA2, four

14 consecutive lows can be identified in respect to a basal level close to the one prevailing at the end of

15 the sequence. The two species that most contribute to CA2 are Rhopalodia gibberula and

16 Stephanodiscus minutulus (Fig. 3). The three first lows of CA2 correspond to peaks in relative

17 abundance of $S$. minutulus and $R$. gibberula, whereas the fourth low is associated with a high

18 relative abundance of $R$. gibberula.

19 The peak of inferred conductivity is a consequence of high variations in relative abundance

20 of several species (Fig. 4). The species Rhopalodia gibberula and Anomoeoneis sculpta had much

21 higher relative abundance at the peak, whereas the relative abundances of Rhopalodia gibba and

22 Stephanodiscus astraea were much lower. Each of these species had a similar relative abundance

23 just before and after the peak. The distributions of the four species along the conductivity gradient

24 of the modern African dataset reveal a zone in the gradient between 3 and 3.5 where the relative

25 abundance of every species is lowest or changes abruptly (Fig. 5). Indeed, this common threshold 
1 appears like an approximate upper limit of conductivity for $R$. gibba and a lower limit for $R$.

2 gibberula and A. sculpta. The species S. astraea is abundant at conductivities either lower or higher

3 than the threshold. The analysis of the modern African dataset by gradient forest (Fig. 6) showed

4 that (1) conductivity was the most important predictor among the five hydrochemical variables, (2)

5 samples were uniformly distributed in the conductivity gradient, and (3) there was a clear peak of

6 split density around $3.2\left(\log \mu \mathrm{cm}^{-1}\right)$. This peak indicates a critical zone in the gradient with

7 maximal turnover of diatom communities.

8

\section{Discussion}

11 When the whole Holocene sediment core from Lake Abiyata is considered (Gasse 2001; Chalié and

12 Gasse 2002), the conspicuous jump in diatom-inferred conductivity at 5.3 ka BP may be interpreted

13 as a rapid change in climate (within a few decades), having immediate repercussions on lake

14 hydrochemistry. The short peak preceding the period of higher conductivity is almost undetectable

15 over such a large time scale. Reports of rapid and synchronous climate changes from coastal

16 sediments in northwest and eastern Africa (deMenocal et al. 2000; Tierney and deMenocal 2013),

17 however, motivated a detailed investigation of this critical period in sediments of Lake Abiyata.

18 There are regional differences in the termination of the African Humid Period across the continent

19 (Burrough and Thomas 2013). Lake Abiyata lies between the Gulf of Aden and Lake Turkana,

20 where paleoclimate records showed rapid, century-scale change to a drier climate (Fig. 1) (Tierney

21 and deMenocal 2013). The detailed analysis of diatom assemblages, with the addition of

22 supplementary samples in the sediment core, yielded evidence of a rapid climate transition at this

23 site, synchronous with other studies.

Focusing on the period 6.5 to $4.5 \mathrm{ka} \mathrm{BP}$, the change in diatom-inferred conductivity appears

25 less abrupt and the single peak preceding the final rise suggests a transition period was already 
1 under way. Inferred conductivity, however, seems to represent only a moderate part of the variation

2 in diatom assemblage composition, judging from the high correlation of inferred conductivity with

3 CA1 (34 \% eigenvalue, Fig. 2). The identification of the transition period between two relatively

4 stable states mainly comes from the variations along CA2. This second dimension shows

5 modifications of diatom assemblages that are not linked to major changes in water conductivity, but

6 likely to other limnological factors influenced by climate, such as water level (P-E balance), mixing

7 (related to temperature and depth), turbidity or nutrient input (via precipitation and erosion). The

8 first stable state is characterized by small planktonic species, and the second stable state is defined

9 by the importance of large, benthic, salt-tolerant species such as Anomoeoneis sculpta or

10 Rhopalodia gibberula (Table 1). These two states correspond to a deep, freshwater lake and a

11 shallow saline lake, respectively. The estimated duration of the transition period ( $<600$ years) is

12 consistent with an abrupt termination of the African Humid Period, as recorded in the Gulf of Aden

13 and Lake Turkana (Tierney and deMenocal 2013).

14 The short peak along CA1 and the regular oscillations along CA2 suggest high variability in

15 the lake during the transition period. The two species, S. minutulus and R. gibberula, which are

16 most related to CA2, may be associated with intermediate states of the lake. Successive dominance

17 of a planktonic species (S. minutulus) and a benthic species ( $R$. gibberula) at peaks in CA2 is

18 consistent with a trend of decreasing water level, but with several reversals. The termination of the

19 African Humid Period was considered a climate regime shift triggered by a gradual decrease in

20 solar irradiance (deMenocal et al. 2000; Foley et al. 2003). A regime shift is likely to be indicated

21 by changes in system dynamics, which can be considered early warning signals (Thomas 2016). A

22 review of eight past climate transitions revealed that most of them were preceded by early warning

23 signals that could be detected statistically in paleoecological time series (Dakos et al. 2008). One of

24 these transitions was North African desertification. Dakos et al. (2008) noticed an increase in

25 autocorrelation before the transition, which is one early warning sign that indicates the system is 
1 slowing down. An increase of variance can be also a sign that a system is losing stability and

2 approaching a tipping point (Thomas 2016). During the transition period, the climate in Ethiopia

3 may have switched between alternative, i.e. arid and humid states. The Lake Abiyata diatom

4 communities probably recorded flickering of the climate before the regime shift. As underlined by

5 Wang et al. (2012), increased variance may be an early warning signal, even in a low-resolution

6 record, but with a constant sampling frequency along the sequence (Carstensen et al. 2013). In this

7 study, the increase in variance observed during the transition is not associated with a higher

8 sampling frequency and is therefore not an artefact.

The short peak of inferred conductivity is a prominent feature of the transition recorded in

10 the sequence. As it is formed by a single sample, its climatic meaning is dubious. This sample,

11 however, may be significant for several reasons. First, sediment reworking would lead to older

12 sediment from the large freshwater lake being re-deposited in the context of a low-stage, saline

13 lake, rather than the contrary. Second, a similar and synchronous peak of diatom-inferred

14 conductivity (a single sample) was recorded in neighboring Lake Tilo at ca. $4800{ }^{14} \mathrm{C}$ a BP (Telford

15 and Lamb 1999). And last, the independent variations of CA2 suggest that rapid lake fluctuations

16 were possible during this transition period. The peak in conductivity (or CA1) may be one additive

17 expression of the variability observed in CA2 during the transition.

18 The question of how the lake water could have reached such high conductivity and returned

19 to a low-salinity condition in only a few decades, remains (Fig. 1). Two possible, non-exclusive

20 explanations for this single peak can be provided, both implying a threshold effect, which enhanced

21 lake response to climate oscillations. First, the lake had probably already decreased in volume

22 substantially by this time and had therefore become responsive to changes in precipitation-

23 evaporation balance. Variations in water conductivity may have been accentuated by a water-level

24 threshold, below which there was no outflow from the lake (a terminal lake) and salts concentrated

25 faster. Subtle fluctuations around such a threshold may have produced large variations in 
1 conductivity. The hypothesis of such a site-specific threshold effect was also proposed to explain

2 the rapid freshwater-to-saline transition recorded in the sediments of Lake Yoa at 4 ka BP (Kröpelin

3 et al. 2008). For the case of Lake Abiyata, hydrological simulations could provide insights into the

4 possibility of such a rapid conductivity change, reconstructed from diatoms.

The other explanation is the existence of an ecological salinity threshold for diatoms. In this

6 case, a modest salinity increase above a threshold would imply an important change in diatom

7 community composition that could have been reversed when conductivity once again fell below the

8 threshold. The conductivity transfer function based on weighted averaging (Gasse et al. 1995;

9 Chalié and Gasse 2002) could thus have exaggerated the amplitude of salinity change. More

10 investigations are needed on the potential effect of ecological thresholds on inferences derived from

11 transfer functions, especially with regard to the number of species involved and their specific

12 tolerances. The main conductivity threshold may be around $3.2\left(1600 \mu \mathrm{S} \mathrm{cm}^{-1}\right)$, as suggested by

13 diatom species distributions in the conductivity gradient of the modern African dataset (Fig. 6).

14 Approximately the same ecological threshold emerged when all species in the dataset were

15 considered (via gradient forest) and when only the four species most associated with the

16 conductivity peak were considered. This suggests an ecological significance of this threshold. The

17 correlations between variables in the modern African dataset, however, suggest that $\mathrm{pH}$ or ionic

18 composition could contribute to this threshold. The species Stephanodiscus astraea exhibits

19 relatively high abundance on either side of the gradient. This suggests that two different ecotypes

20 might have been included in the same morphotype. The threshold identified in this study is close to

21 the freshwater-oligohaline limit generally accepted for saline lakes using ecological or

22 physiological criteria (Hammer 1986).

24 Conclusions 
1 Although the time resolution was low, the diatom record from Lake Abiyata revealed interesting

2 features about the termination of the African Humid Period in Ethiopia. A transition period was

3 clearly delimited from variations in diatom assemblages. Its duration was estimated to be $<600$

4 years and it may correspond to a period of climate transition characterized by high climate

5 variability (rainfall). The variations in diatom assemblages suggest climate oscillations whose effect

6 on the lake may have been enhanced by site-specific or ecological thresholds. These oscillations

7 may represent early warning signals that preceded the climate regime shift to arid conditions. The

8 termination of the African Humid Period may not have been a progressive drop in monsoon

9 intensity as suggested by low-resolution oceanic records that integrate information over large areas.

10 In central Ethiopia, it was instead a period of humid climate interrupted by severe droughts that

11 probably had catastrophic effects on terrestrial ecosystems and human populations as early as $5.8 \mathrm{ka}$

12 BP.

14 Acknowledgements

16 We thank Jean-Charles Mazur (CEREGE) for slide preparation of the new analyzed samples.

17 Sediment core samples were collected under the auspices of CNRS-INSU Programs PNEDC-

18 ERICA ('Environmental Research for Intertropical Climate in Africa', R.Bonnefille, coord.), and

19 ECLIPSE-CLEHA ('CLimat, Environnement et dynamique des populations Humaines en Afrique

20 de l'Est depuis 20,000 ans’, D.Williamson coord.). We are grateful to Keely Mills for valuable

21 comments and suggestions that greatly improved the manuscript, and to an anonymous reviewer for

22 helpful comments.

24 References 
1 Ayenew T (2007) Water management problems in the Ethiopian rift: Challenges for development. J

2 African Earth Sci 48:222-236

3 Battarbee R, Juggins S, Gasse F, Erson NJ, Bennion H, Cameron NG (2000) European Diatom

4 Database Initiative (EDDI), http://craticula.ncl.ac.uk/Eddi/jsp/index.jsp

5 Burrough SL, Thomas DSG (2013) Central southern Africa at the time of the African Humid Period:

6 a new analysis of Holocene palaeoenvironmental and palaeoclimate data. Quaternary Sci Rev

$7 \quad 80: 29-46$

8 Carstensen J, Telford RJ, Birks HJB (2013) Diatom flickering prior to regime shift. Nature 498:E11

9 Chalié F, Gasse F (2002) Late Glacial-Holocene diatom record of water chemistry and lake level

10 change from the tropical East African Rift Lake Abiyata (Ethiopia). Palaeogeogr Palaeoclimatol

11 Palaeoecol 187:259-283

12 Cocquyt C (1998) Diatoms from the Northern Basin of Lake Tanganyika. Bibliotheca Diatomologica 13 39, Stuttgart, 275 pp

14 Dakos V, Scheffer M, van Nes EH, Brovkin V, Petoukhov V, Held H (2008) Slowing down as an early

15 warning signal for abrupt climate change. Proc Natl Acad Sci USA 105:14308-14312

16 David WR (2016) labdsv: Ordination and Multivariate Analysis for Ecology. R package version 1.8-0

17 https://CRAN.R-project.org/package=labdsv

18 deMenocal P, Bond G (1997) Holocene climate less stable than previously thought. Eos, Trans Am

19 Geophys Union 78:447-454

20 deMenocal P, Ortiz J, Guilderson T, Adkins J, Sarnthein M, Baker L, Yarusinsky M (2000) Abrupt

21 onset and termination of the African Humid Period: rapid climate responses to gradual insolation

22 forcing. Quaternary Sci Rev 19:347-361 
1 Ellis N, Smith SJ, Pitcher CR (2012) Gradient forests: calculating importance gradients on physical

2 predictors. Ecology 93:156-168

3 Foley JA, Coe MT, Scheffer M, Wang GL (2003) Regime shifts in the Sahara and Sahel: Interactions

4 between ecological and climatic systems in northern Africa. Ecosystems 6:524-539

5 Gasse F (1986) East African diatoms: Taxonomy, Ecological Distribution. Bibliotheca Diatomologica

6 11. Cramer, Berlin, 201 pp

7 Gasse F (2001) Paleoclimate- Hydrological changes in Africa. Science 292:2259-2260

8 Gasse F, Juggins S, Ben Khelifa L (1995) Diatom-Based Transfer-Functions for Inferring Past

9 Hydrochemical Characteristics of African Lakes. Palaeogeogr Palaeoclimatol Palaeoecol 117:31-54

10 Gibert E, Travi Y, Massault M, Chernet T, Barbecot F, Laggoun-Defarge F (1999) Comparing

11 carbonate and organic AMS-C-14 ages in Lake Abiyata sediments (Ethiopia): Hydrochemistry and

12 paleoenvironmental implications. Radiocarbon 41:271-286

13 Gillespie R, Street-Perrott FA, Switsur R (1983) Post-Glacial arid episodes in Ethiopia have

14 implications for climate prediction. Nature 306:680-683

15 Juggins S (2013) Quantitative reconstructions in palaeolimnology: new paradigm or sick science?

16 Quaternary Sci Rev 64:20-32

17 Hammer UT (1986) Saline Lake Ecosystems of the World. Monographiae Biologicae, XI, Springer

18 Netherlands, $616 \mathrm{pp}$

19 Hustedt F (1949) Exploration du Lac National Albert: Süsswasser Diatomen aus dem Albert-National

20 Park in Belgisch-Kongo. Mission H. Damas (1935-36), Brussels, 199 pp

21 Krammer K, Lange-Bertalot H (1986-88-91a,b) Süsswasserflora von Mitteleuropa:

22 Bacillariophyceae, 1-4, Gustav Fischer Verlag, Jena 
1 Kröpelin S, Verschuren D, Lezine AM, Eggermont H, Cocquyt C, Francus P, Cazet JP, Fagot M,

2 Rumes B, Russell JM, Darius F, Conley DJ, Schuster M, von Suchodoletz H, Engstrom DR (2008)

3 Climate-driven ecosystem succession in the Sahara: The past 6000 years. Science 320:765-768

4 R Core Team (2016). R: A language and environment for statistical computing. R Foundation for

5 Statistical Computing, Vienna, Austria. URL https://www.R-project.org/

6 Roubeix V, Danis PA, Feret T, Baudoin JM (2016) Identification of ecological thresholds from

7 variations in phytoplankton communities among lakes: contribution to the definition of

8 environmental standards. Environ Monit Assess 188: 246. https://doi.org/10.1007/s10661-016-

$9 \quad 5238-y$

10 Scheffer M, Carpenter SR (2003) Catastrophic regime shifts in ecosystems: linking theory to

11 observation. Trends Ecol Evol 18:648-656

12 Seddon AWR, Froyd CA, Witkowski A, Willis KJ (2014) A quantitative framework for analysis of

13 regime shifts in a Galapagos coastal lagoon. Ecology 95:3046-3055

14 Stuiver M, Reimer PJ (1993) Extended C-14 Data-Base and Revised Calib 3.0 C-14 Age Calibration

15 Program. Radiocarbon 35:215-230

16 Stuiver M, Reimer PJ, Bard E, Beck JW, Burr GS, Hughen KA, Kromer B, McCormac G, Van der

17 Plicht J, Spurk M (1998) INTCAL98 radiocarbon age calibration, 24,000-0 cal BP. Radiocarbon

$18 \quad 40: 1041-1083$

19 Telford RJ, Lamb HF (1999) Groundwater-mediated response to Holocene climatic change recorded

20 by the diatom stratigraphy of an Ethiopian crater lake. Quaternary Res 52:63-75

21 ter Braak CJF, Looman CWN (1986) Weighted averaging, logistic regression and the Gaussian

22 response model. Vegetatio 65:3-11 
1 Thomas ZA (2016) Using natural archives to detect climate and environmental tipping points in the

2 Earth System. Quaternary Sci Rev 152:60-71

3 Tierney JE, deMenocal PB (2013) Abrupt shifts in horn of Africa hydroclimate since the Last Glacial

4 Maximum. Science 342:843-846

5 Walker B, Meyers JA (2004) Thresholds in ecological and social-ecological systems: a developing

6 database. Ecol Soc 9(2)

7 Wang R, Dearing JA, Langdon PG, Zhang EL, Yang XD, Dakos V, Scheffer M (2012) Flickering

8 gives early warning signals of a critical transition to a eutrophic lake state. Nature 492:419-422 
1 Table 1 List of indicator species in the groups of samples before (group 1) and after (group 2) the

2 climate transition, with their indicator value (IndVal) and p values from significance test, and their

3 conductivity optima and tolerance in the transfer function

\begin{tabular}{lccccc}
\hline \multicolumn{1}{c}{ Species } & Group & IndVal & p value $\begin{array}{c}\text { Conductivity } \\
\text { Optimum } \\
\left(\log \mu \mathrm{Sm}^{-1}\right)\end{array}$ & $\begin{array}{c}\text { Tolerance } \\
(\log \mu S \\
\left.\mathrm{cm}^{-1}\right)\end{array}$ \\
\hline Amphora pediculus (Kützing) Grunow & 1 & 0.84 & 0.001 & 2.73 & 0.37 \\
Cocconeis thumensis A.Mayer & 1 & 0.38 & 0.041 & 1.84 & 0.6 \\
Fragilaria brevistriata Grunow & 1 & 0.79 & 0.001 & 2.76 & 0.8 \\
Fragilaria capucina Desmazieres & 1 & 0.5 & 0.01 & 2.53 & 0.34 \\
Fragilaria construens (Ehrenberg) Grunow f. construens & 1 & 0.84 & 0.002 & 2.71 & 0.72 \\
Fragilaria zeilleri Héribaud & 1 & 0.75 & 0.001 & 3.03 & 0.7 \\
Navicula seminuloides Hustedt in A. Schmidt & 1 & 0.63 & 0.035 & 2.99 & 0.98 \\
Nitzschia amphibia Grunow f. rostrata Hustedt & 1 & 1 & 0.001 & & \\
Nitzschia epiphytica O.Muller & 1 & 0.82 & 0.001 & 2.44 & 1.03 \\
Stephanodiscus astraea (Ehrenberg) Grunow & 1 & 0.95 & 0.001 & 2.67 & 1.03 \\
Stephanodiscus medius Håkansson & 1 & 0.99 & 0.001 & 2.67 & 1.03 \\
Anomoeoneis sculpta (Ehrenberg) Cleve & 2 & 1 & 0.001 & 4.23 & 0.43 \\
Amphora veneta Kützing & 2 & 0.64 & 0.018 & 3.06 & 0.64 \\
Aulacoseira granulata (Ehrenberg) Simonsen & 2 & 0.55 & 0.034 & 2.14 & 0.46 \\
Nitzschia amphibia Grunow f. amphibia & 2 & 0.5 & 0.043 & 2.66 & 0.75 \\
Rhopalodia gibberula (Ehrenberg) O.Muller & 2 & 0.99 & 0.001 & 3.91 & 0.46 \\
Surirella ovalis Brebisson & 2 & 0.64 & 0.018 & 3.18 & 0.78 \\
\hline
\end{tabular}


1 Fig. 1 The termination of the African Humid Period in East Africa through hydroclimate proxies in

2 Holocene sediment records. (a) Hydrogen isotope composition of leaf waxes in a core from the Gulf

3 of Aden (from Tierney and deMenocal 2013), (b) diatom-inferred conductivity of Lake Abiyata

4 (from Chalié and Gasse 2002), (c) same data with a focus on the period from 6.5 to 4.5 cal ka BP

5 and addition of new samples (empty circles) and (d) location of the Zwai-Shalla lake system

6 including Lake Abiyata. The dashed line represents the shoreline of the middle Holocene Lake and

7 the star indicates the coring site.

8 Fig. 2 Correspondence analysis of diatom samples from the period 6.5 to $4.5 \mathrm{cal} \mathrm{ka}$ BP.

9 Representation of the samples in the two first dimensions with \% eigenvalue barplot (a) and

10 variations through time in the first (CA1, 34\% [b]), second (CA2, 24\% [c]) and third (CA3, 12\%

11 [d]) dimensions. Groups 1 and 2 correspond to the samples before and after the transition period,

12 respectively. The grey band represents the transition period with higher variability of the

13 assemblages; its time limits are given by the estimated dates for the latest sample in group 1 (5821

14 cal a BP) and the first sample in group 2 (5229 cal a BP). The maximum duration of the transition

15 period is therefore estimated about 600 years

16 Fig. 3 Variations through time in relative abundance of the two diatom species, Rhopalodia gibba

17 and Stephanodiscus minutulus, which contribute most to the second axis of the correspondence

18 analysis (CA2) as shown by the barplot of species contributions

19 Fig. 4 Relative abundance of the four diatom species Rhopalodia gibba, Stephanodiscus astraea,

20 Rhopalodia gibberula and Anomoeoneis sculpta, showing the largest variations among the three

21 consecutive sediment samples forming the diatom-inferred conductivity peak before 5.5 cal ka BP.

22 Dates were estimated using the core age model (Chalié and Gasse 2002)

23 Fig. 5 Relative abundance of the species Rhopalodia gibba, Stephanodiscus astraea, Rhopalodia

24 gibberula and Anomoeoneis sculpta in the conductivity gradient of the modern African diatom

25 dataset. The grey band indicates a potential community threshold 
1 Fig. 6 Result of gradient forest analysis on the modern African diatom dataset. The barplot in the

2 top left corner represents the relative importance of the five hydrochemical variables used in the

3 analysis (Cond = conductivity, Alk = alkalinity). The lines in the graph are the density of splits (i.e.

4 breakpoints) in the conductivity gradient (black line), the density of data (dashed line) and the ratio

5 of densities (grey line). The peaks of the ratio of densities indicate potential ecological community

6 thresholds

7 


\section{Fig. 1}
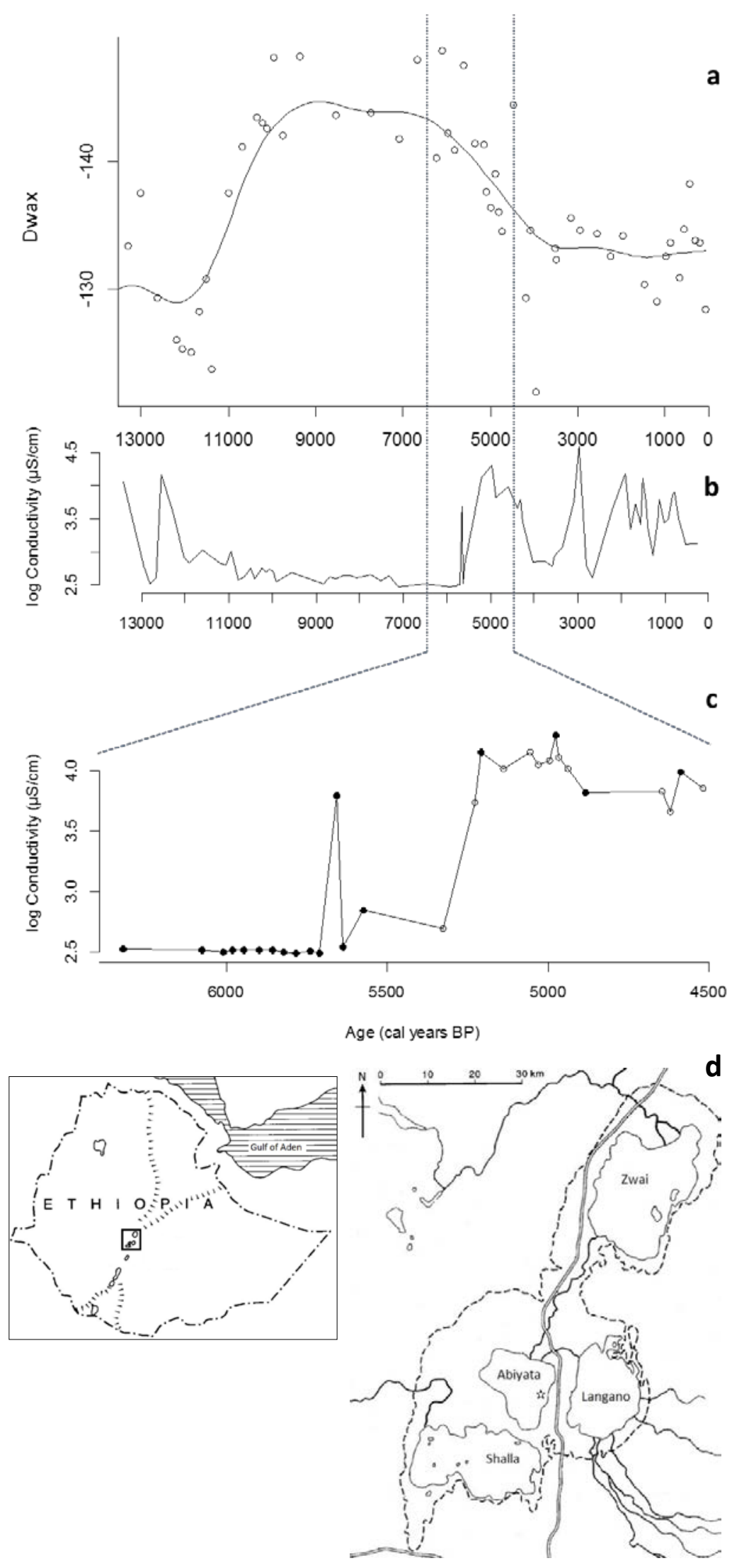


\section{Fig. 2}
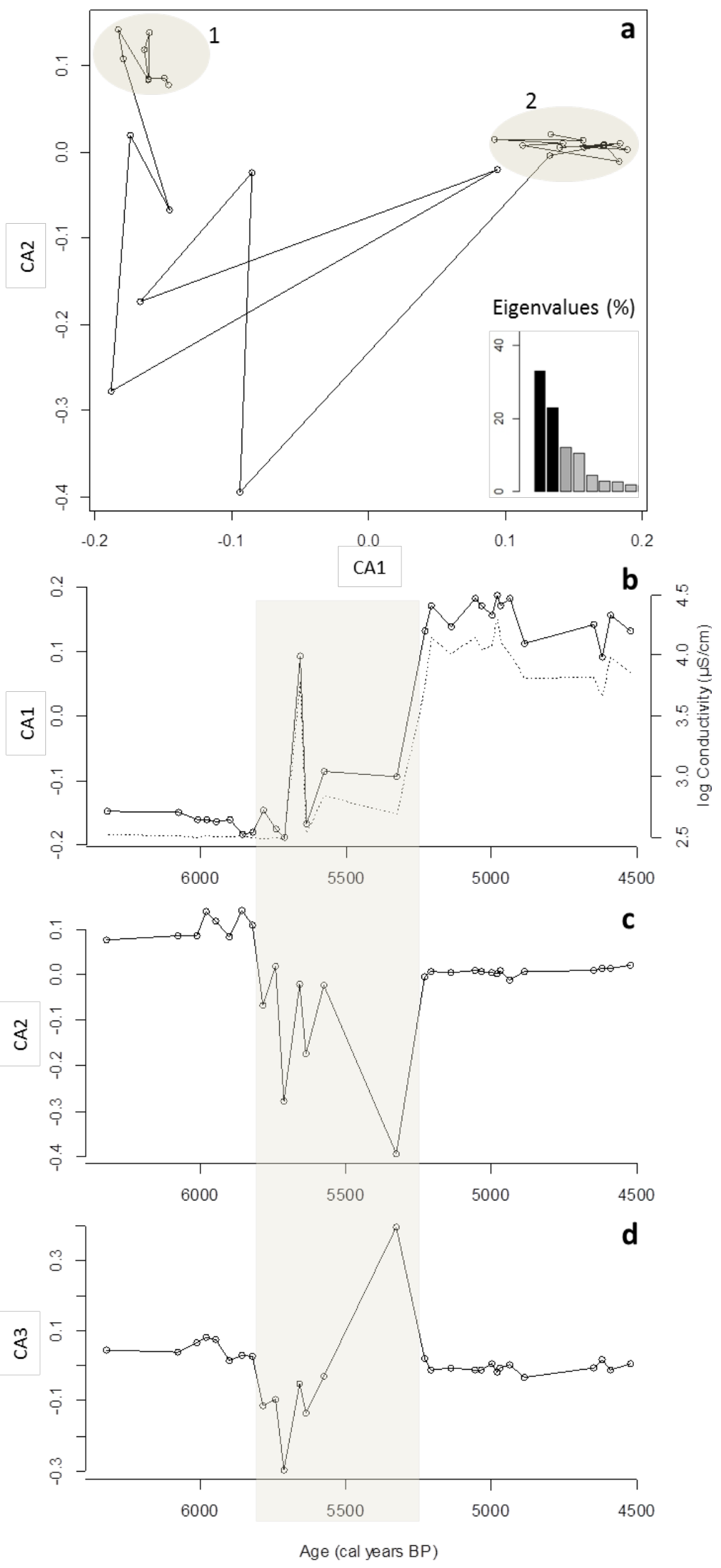


\section{Fig. 3}

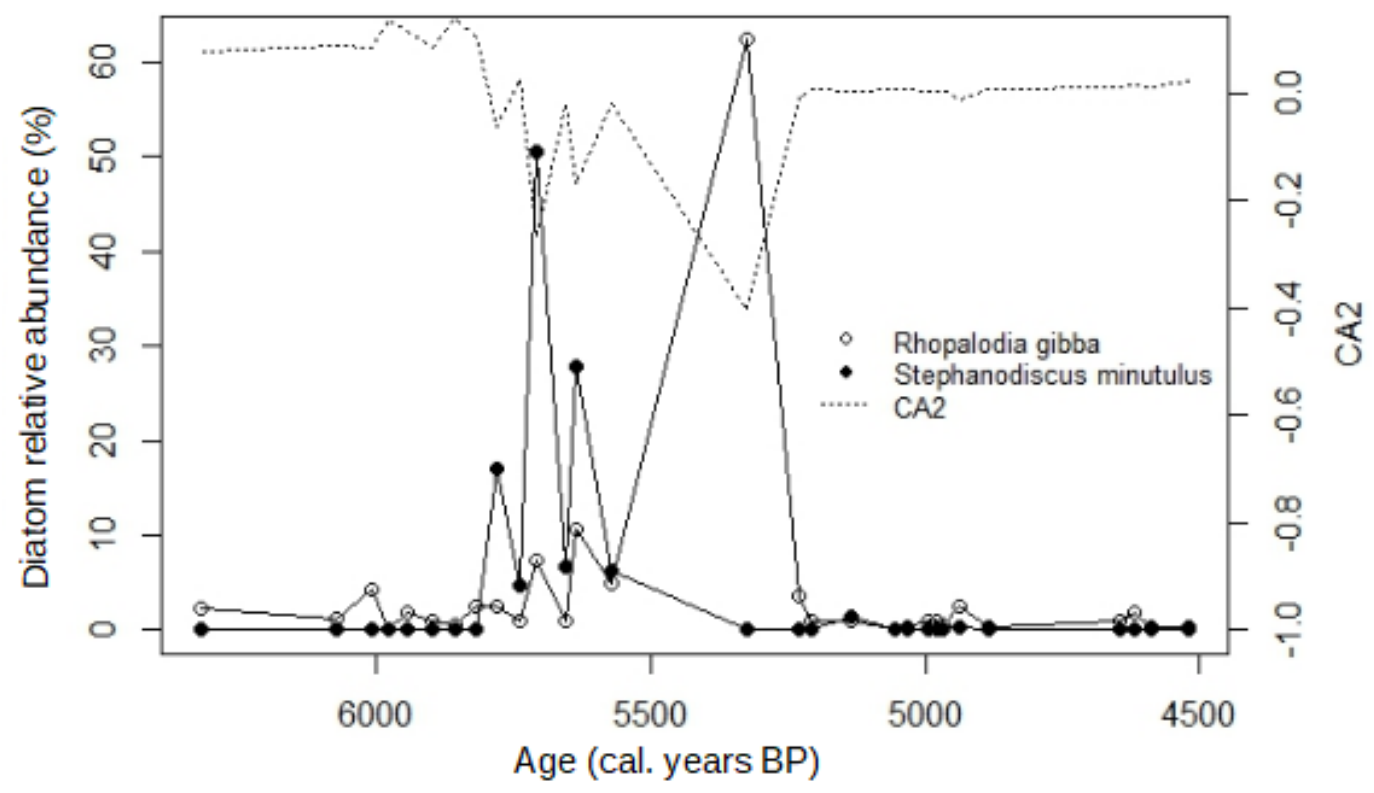

Nitzschia amphibia Amphora pediculus Nitzschia amphibia f. rostrata Stephanodiscus medius Fragilaria capitata Cocconeis thumensis Fragilaria $\mathrm{sp}$ Fragilaria zeilleri Stephanodiscus minutulus Rhopalodia gibba

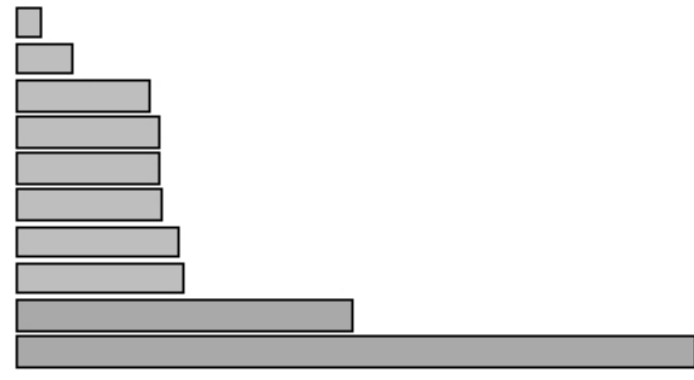

\begin{tabular}{|c|c|c|c|c|}
\hline$\Gamma$ & $T$ & $T$ & $T$ & $T$ \\
\hline- & ণ্ণ & ষ্. & $\begin{array}{l}\mathscr{O} \\
\stackrel{\circ}{\circ}\end{array}$ & $\begin{array}{l}\text { O̊ } \\
\end{array}$ \\
\hline
\end{tabular}


1 Fig. 4

2

3

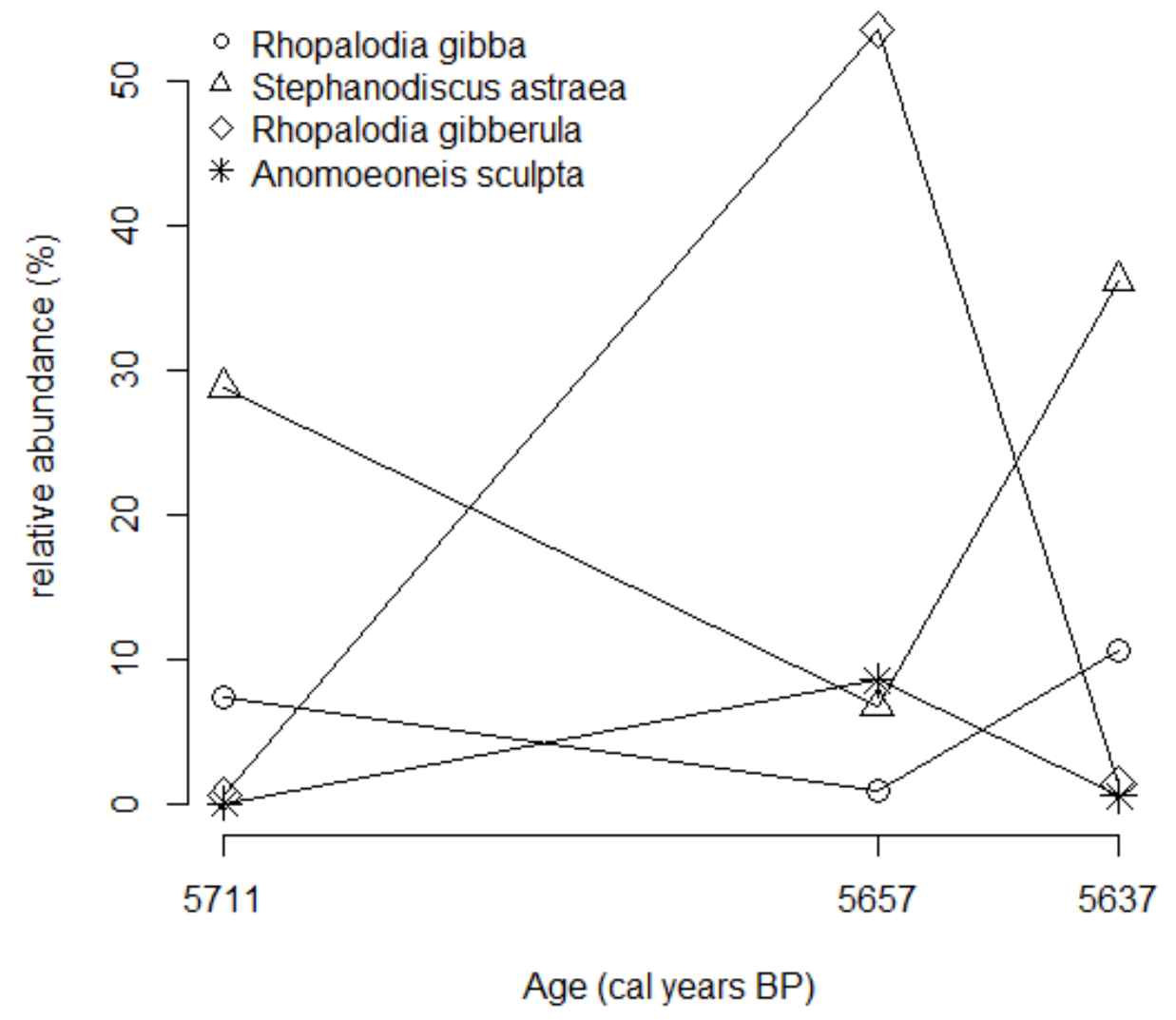

4 


\section{Fig. 5}
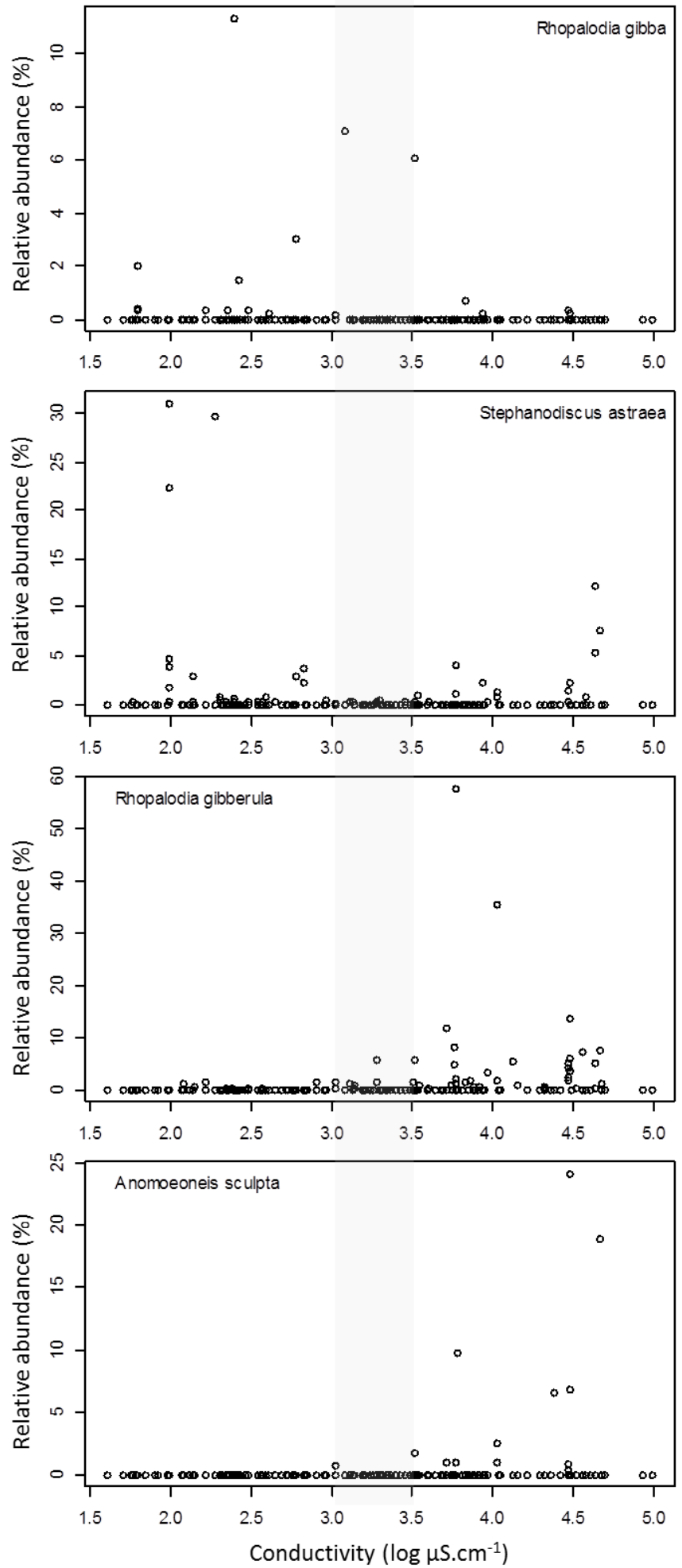


\section{Fig. 6}

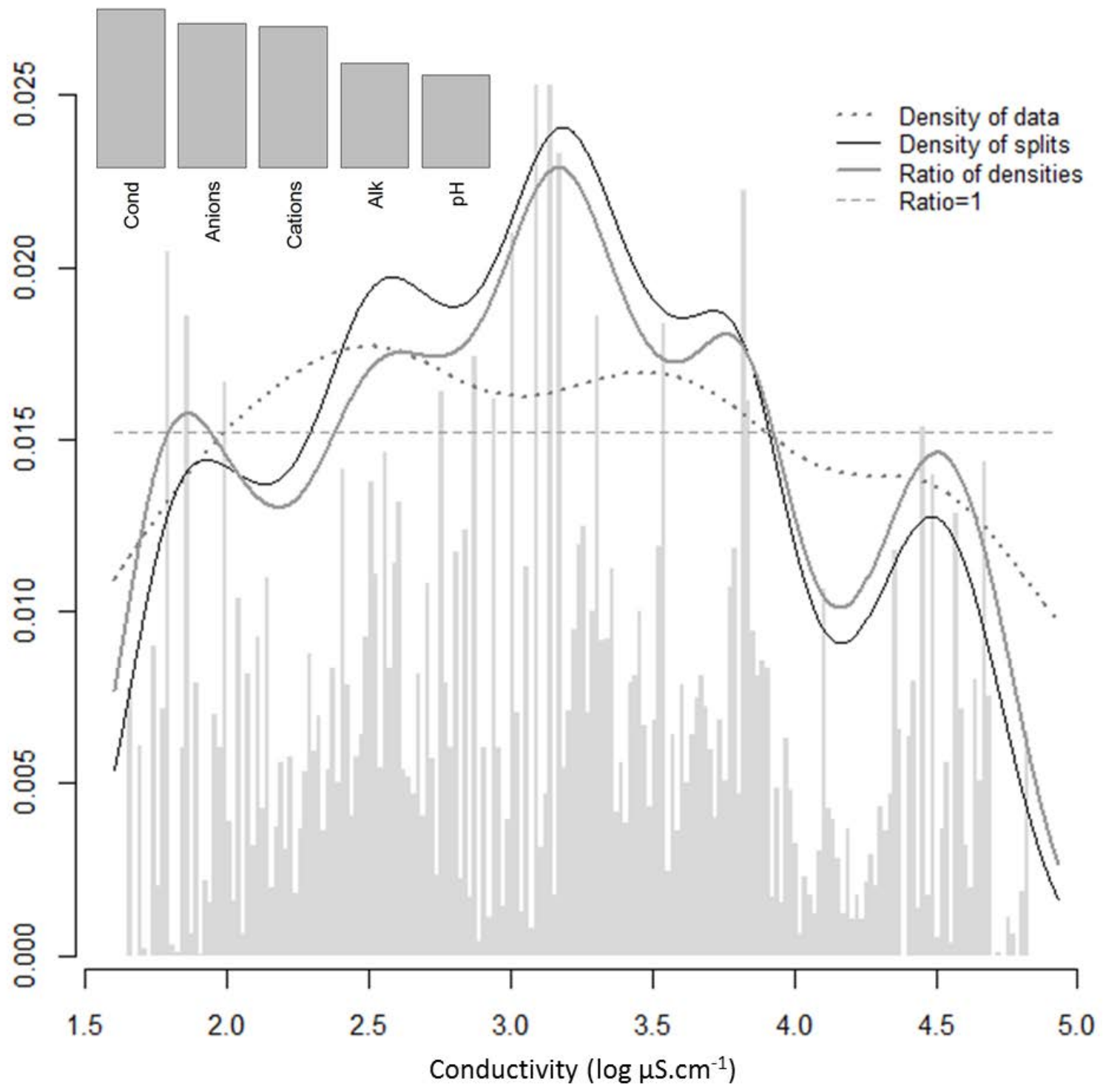

